\title{
Effect of Gamma Radiation Dosages on Rooting of Pineapple Crown Sections, Shoot Emergence and Growth
}

\author{
H. Irizarry and J. Vélez Fortuño
}

INTRODUCTION

Mutation breeding may be an indispensable tool in a variety improvement program, especially with fruit crops that are vegetatively propagated, effected by self-sterility, incompatibility, etc. In clonally-propagated crops, this breeding method is advantageous because desirable mutants can be fixed readily by vegetative propagation. The long vegetative period from germination to flowering in many tree crops also constitutes an additional barrier to their improvement through standard breeding procedures. Numerous spontaneous mutants have been observed in many fruit crops, several of which proved of great commercial value. These have influenced further attempts to induce mutations in such crops by means of artificial procedures.

Ionizing radiation, among the mutagenic agents, has been used widely by many investigators to induce somatic changes in asexually-propagated plants $(1,8,4,5,7) .{ }^{2}$ Vegetative propagation insures the preservation and rapid multiplication of any resulting stable change.

The pineapple, Ananas comosus, L., which congregates the described features, was subjected to gamma radiation for the purpose of studying the effects of such radiation on the plant and fruit character complex. Variety Smooth Cayenne was chosen for this study because clonal variations have been observed frequently in commercial plantings of Cayenne (2,6). It was expected that radiation would further increase variability in this variety. Einset and Pratt ( 8 ) suggested that the most promising application of radiation to fruit breeding lies in the possibility of inducing favorable changes in existing commercial varieties.

This paper presents initial information concerning the response of pineapple crown tissue to the action of different levels of gamma radiation.

1 Assistant Plant Breeder, and Head Plant Breeding Department, respectively, Agricultural Experiment Station, Mayagüez Campus, University of Puerto Rico, Río Piedras, P.R.

The authors are grateful to Dr. R. Llice, Principal Scientist, and Mr. J. Roldán, former Research Associate Scientist, Agricultural Bio-Science Division, Puerto Rico Nuclear Center, Rio Piedras, P.R. for their assistance and advice rendered during the irradiation process.

Italic numbers in parentbeses refer to Literature Cited, pp. 558. 


\section{MATERIALS AND METHODS}

Pineapple fruit crowns were divided longitudinally into three to four sections. This vegetative part was selected for testing because the crown is a continuation of the original plant meristem in which a large number of dormant axillary buds are concentrated (2). Nybom (7) suggested the irradiation of dormant scions to induce somatic mutations in fruit trees.

Prior to irradiation, the average weight per section was tabulated. Also, the plant material was dipped in Malathion ${ }^{3}$ solution (10 cc./gal. of water) to kill insects that might be present and dusted with Arasan 75 to prevent possibility of fungus attack through the cuts.

The crown pieces were selected at random in groups of 40 each, and placed on a supporting wooden board consisting of 3 panels (15 X 15 inches) joined together at an inside angle of approximately $120^{\circ}$. The sections were fastened individually to the board and the board then placed 1 meter away from the cobalt- 60 source. A dosimetry reading was taken at different points of the board before the irradiation of the material. This reading was used to calculate the dose in rads per hour.

Seven groups were exposed to doses of $500,750,1,000,1,500,2,000$, 2,500 and 3,000 rads, respectively, in December 1965. The treated groups, with a check, were planted December 22 in metal flats containing steamsterilized soil. At planting time 1 ounce of a 12-2-10 fertilizer was applied to each flat.

Due to lack of response in the first study, a second test was initiated in February 1966. In this test four groups of 40 sections each were exposed to gamma-ray doses of $4,000,8,000,16,000$, and 32,000 rads. This plant material, with a check group, was handled as in the first test. It was planted on February 11.

Observations on rooting of crown pieces, sprouting of germinal buds, and number of shoots borne, were recorded at weekly intervals throughout a year for each treatment. Growth measurements were taken to detect stunting at the time of detaching the young shoots from the rooted sections. These measurements were taken from the base of the newly detached shoots to the tip of the longest leaf, referred to as $D$ leaf in pineapple.

The detached $X_{1}$ plants (shoots developed from irradiated sections) and the checks (shoots originated from non-irradiated sections) were transplanted to polyethylene bags filled with sterilized soil. Shoot detaching was practiced eight and six times in experiments 1 and 2 respectively.

- Trade names are used in this publication solely for the purpose of providing specific information. Mention of a trade name does not constitute a guarantee, warranty, or endorsement by the Agricultural Experiment Station of the University of Puerto Rico indicating superiority to any other similar product not mentioned. 


\section{RESULTS AND DISCUSSION}

Data on the number and percentage of rooted sections at different doses are presented in table 1. Response to dosages from 500 to 3,000 rads appears to have been very irregular or inconsistent, and indicated no defined trend. Doses of 500, 1,500 and 2,500 rads did not reduce rooting. There was a reduction, however, in the rooting percentage after treatments with $750,1,000,2,000$ and 3,000 rads. Exposure to 8,000 and 16,000 rads reduced

TABLE 1.-Effect of gamma radiation on rooting, bud sprouting, and shoot emergence of pineapple crown sections

\begin{tabular}{|c|c|c|c|c|c|c|c|}
\hline \multirow{2}{*}{$\frac{\text { Gamma-ray dose }}{\text { Rads }}$} & \multirow{2}{*}{$\begin{array}{c}\begin{array}{c}\text { Sections } \\
\text { propagated }\end{array} \\
\text { Number }\end{array}$} & \multicolumn{3}{|c|}{ Sections rooted } & \multirow{2}{*}{$\begin{array}{c}\begin{array}{c}\text { Time required } \\
\text { for first buds } \\
\text { to sprout }\end{array} \\
\text { Days }\end{array}$} & \multicolumn{2}{|c|}{$\begin{array}{l}\text { Average shoot emergence } \\
\text { per section }\end{array}$} \\
\hline & & Number & Percent & $\begin{array}{c}\text { Percent of } \\
\text { control }\end{array}$ & & Number & $\begin{array}{c}\text { Percent of } \\
\text { control }\end{array}$ \\
\hline \multicolumn{8}{|c|}{ First experiment } \\
\hline 0 & 40 & 39 & 97.5 & 100.0 & 34 & 5.4 & 100.0 \\
\hline 500 & 34 & 34 & 100.0 & 102.5 & 34 & 4.5 & 83.3 \\
\hline 750 & 34 & 29 & 85.3 & 87.4 & 34 & 4.1 & 75.9 \\
\hline 1,000 & 33 & 31 & 93.9 & 96.3 & 34 & 4.3 & 79.6 \\
\hline 1,500 & 35 & 35 & 100.0 & 102.5 & 34 & 5.0 & 92.5 \\
\hline 2,000 & 36 & 35 & 97.2 & 99.6 & 34 & 5.5 & 101.8 \\
\hline 2,500 & 36 & 36 & 100.0 & 102.5 & 34 & 4.9 & 90.7 \\
\hline 3,000 & 36 & 33 & 91.7 & 94.0 & 34 & 5.2 & 96.2 \\
\hline
\end{tabular}

Second experiment

\begin{tabular}{r|r|r|r|r|r|r|r}
\hline 0 & 40 & 29 & 72.5 & 100.0 & 32 & 5.2 & 100.0 \\
4,000 & 40 & 28 & 70.0 & 96.5 & 39 & 5.4 & 103.8 \\
8,000 & 40 & 22 & 55.0 & 75.8 & 46 & 3.5 & 67.3 \\
16,000 & 40 & 4 & 10.0 & 13.7 & 145 & 2.6 & 50.0 \\
32,000 & 40 & 0 & - & - & - & - & - \\
\hline
\end{tabular}

the rooting of crown sections in approximately 24 and 86 percent, respectively, as compared with the check. No rooting occurred in crowns exposed to 32,000 rads.

Although thorough disease control measures were applied, several sections became infected with the fungus Thielaviopsis paradoxa (de Seynes) von Höehnel and these were discarded before planting, resulting in an uneven number of propagated and rooted crown sections in experiment 1. The pattern of radiation dosage effect appears to deviate somewhat from that generally expected. The exact cause of this deviation is not known, but 
some of the sections planted might have been infected with the fungus prior to planting causing rooting failure, thus affecting the expected pattern of radiosensitivity. Rooting percentage normally should decrease with increasing dosages of radiation.

In general, the condition of the material used in both experiments appeared to be uniform, but the unequal rooting percentage in the experimental checks (table 1), together with the crown section weight, suggests the occurrence of unrevealed physiological dissimilarities in the plant material. The rooting percentage of the check in experiment 1 was 97.5

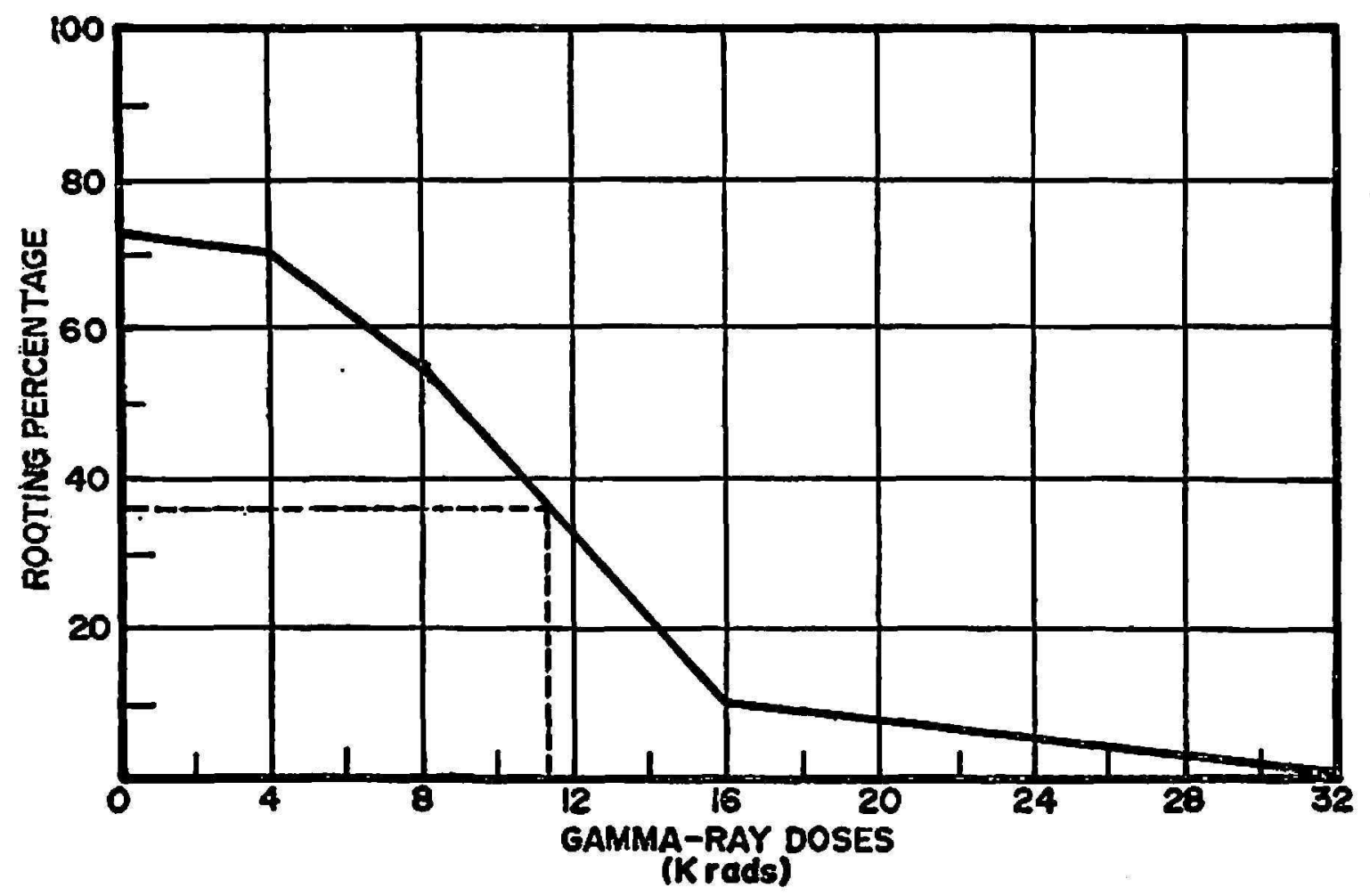

Fia. 1.-Survival curve of pineapple fruit crown sections treated with different doses of gamma radiation in experiment 2.

compared with 72.5 for experiment 2 . The average section weight in the first experiment was $52 \mathrm{~g}$. and $61.6 \mathrm{~g}$. in the second.

The survival percentage, as affected by the radiation, is presented in figure 1. By extrapolation the survival curve indicates that 50 percent of the expected rooting population in experiment 2 could survive a gamma-ray dose of 11,000 rads.

The estimated radiation dose at which 50 percent of the population of pineapple crown sections would survive is considerably higher than that for other crops. Lewis et al. (5), recommended 800 rads as a suitable dose for sweet cherry buds. Nybon (7) in summarizing published reports from mutation breeding suggested an optimal dose of 4,000 rads for treating 
potato tubers. Bauer (1) reported that 6,000 rads appeared to be lethal in the treatment of black currant cuttings.

Lateral branch buds in the 0 - to 3,000-rad treatments started sprouting on the 32nd to the 34th day after planting, thus indicating that radiations up to the level of 3,000 rads did not affect the rate of sprouting. A delay

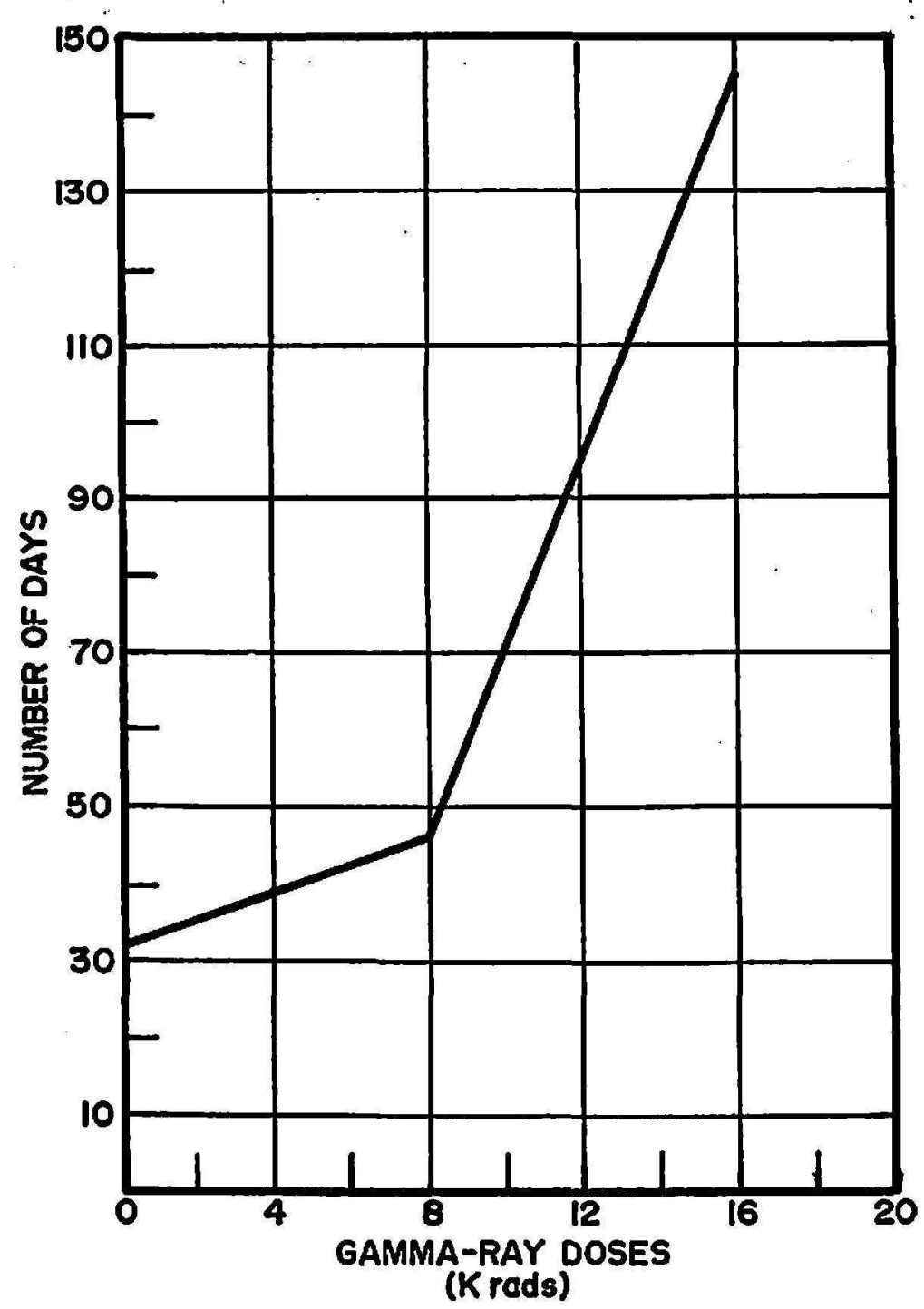

Fia. 2.-Effect of gamma radiation dosages on the sprouting time of lateral, branch buds of pineapple crown sections (experiment 2). No sprouting occurred in the 32,000 rad treatment.

in bud sprouting was detected, however, in treatments above the 3,000-rad level as shown in table 1 and figure 2 . In these treatments, the number of days required for bud sprouting increased as radiation dosage increased. For instance, 145 days were required for the first buds to emerge in the 16,000 -rad treatment whereas no sprouting occurred in the 32,000-rad treatment. This delay in the sprouting of buds probably is caused by an abnormal cell multiplication. Sparrow (8) stated retardation or inhibition of cell divi- 
sion occurs whenever suitable doses of ionizing radiation are delivered to a tissue which normally undergoes further cell multiplication. Such disturbances may be caused by the inhibition of DNA or other genetic damage according to this report.

The number of shoots emerging from the rooted crown sections was not affected by radiation up to the 4,000-rad level as indicated in table 1 . There was, however, a reduction of 33 and 50 percent in the average

TABLE 2.-Effect of gamma radiation dosages on time interval from sprouting of lateral branch buds to first shoot detachment and shoot size from treated pineapple crown sections

\begin{tabular}{|c|c|c|c|c|}
\hline \multirow{2}{*}{$\frac{\text { Gamma-ray dose }}{\text { Rads }}$} & \multirow{2}{*}{$\frac{\text { Shoots detached }}{\text { Number }}$} & \multicolumn{2}{|c|}{$\begin{array}{l}\text { Time interval from sprouting to first } \\
\text { shoots detachment }\end{array}$} & \multirow{2}{*}{$\begin{array}{c}\begin{array}{c}\text { Average shoot size at } \\
\text { detaching time }\end{array} \\
\text { Inches }\end{array}$} \\
\hline & & Days & Mean & \\
\hline \multicolumn{5}{|c|}{ First experiment } \\
\hline $\begin{array}{r}0 \\
500 \\
750 \\
1,000 \\
1,500 \\
2,000 \\
2,500 \\
3,000\end{array}$ & $\begin{array}{l}36 \\
39 \\
24 \\
22 \\
27 \\
26 \\
27 \\
22\end{array}$ & $\begin{array}{c}\text { 32-46 } \\
\text { do. } \\
\text { do. } \\
\text { do. } \\
\text { do. } \\
\text { do. } \\
\text { do. } \\
\text { do. }\end{array}$ & $\begin{array}{l}39.0 \\
\text { do. } \\
\text { do. } \\
\text { do. } \\
\text { do. } \\
\text { do. } \\
\text { do. } \\
\text { do. }\end{array}$ & $\begin{array}{l}5.0 \\
5.6 \\
5.6 \\
5.2 \\
4.8 \\
4.5 \\
4.3 \\
4.8\end{array}$ \\
\hline \multicolumn{5}{|c|}{ Second experiment } \\
\hline $\begin{array}{r}0 \\
4,000 \\
8,000 \\
16,000 \\
32,000\end{array}$ & $\begin{array}{r}31 \\
30 \\
32 \\
7 \\
0\end{array}$ & $\begin{array}{c}21-56 \\
21-49 \\
50-99 \\
83.97 \\
-\end{array}$ & $\begin{array}{c}38.5 \\
35.0 \\
74.5 \\
90.0 \\
-\end{array}$ & $\begin{array}{l}7.0 \\
6.5 \\
6.3 \\
4.0 \\
-\end{array}$ \\
\hline
\end{tabular}

number of shoots in the 8,000 - and 16,000-rad treatments, respectively. No shoot emergence occurred in the 32,000 treatment.

It may be concluded that acute radiation beyond 4,000 rads causes a reduction in the proliferation of shoots, resulting in a lower number of shoots emerging from each rooted section. This reduction probably is caused by the destruction of potential germinal buds by irradiation beyond the 4,000-rad level.

A radiation effect on the growth of shoots was detected in treatments above 4,000 rads according to the data in table 2. At the time of the first detaching of the shoots in each treatment, the average shoot size in the 
4,000- and 8,000-rad treatments was similar. However, the number of days required by shoots from the 8,000 - rad treatment to reach that particular stage of growth was more than twice that required by shoots from the 4,000-rad treatment. A severe dwarfing effect on growth was observed in young shoots at the 16,000-rad dose level as presented in table 2 . These findings are in accordance with those of Sparrow (8) who stated plant stuntiness increases with an increase in the radiation dose.

The results in general indicate that low doses of gamma radiation of $\mathbf{5 0 0}$ to 4,000 rads did not produce observable effects on rooting of pineapple crown sections, proliferation of shoots, or initial shoot growth, except in the case of the sprouting time of lateral branch buds, which were retarded by the 4,000-rad dose. Treatments above 4,000 rads reduced rooting of crown sections, the proliferation of shoots, and increased the sprouting time of lateral branch buds. The 32,000-rad treatment destroyed the lateral branch buds.

Sparrow (9) reported on the radiosensitivity of various plants to chronic gamma irradiation through evaluation of the effects at different levels of irradiation and presented information on the principal nuclear and allied factors influencing plant radiosensitivity. He cited high chromosome number, high degree of ploidy, asexual reproduction and other factors tending toward high resistance to radiosensitivity.

In relation to the relative radiosensitivities of different plant species, the higher the dosage, the detrimental effects on growth increase until a dosage level is reached which causes the death of the plant. Species vary from low to high in their resistance to irradiation. Pineapple, according to this study, can be grouped among the plant species highly resistant to irradiation.

\section{SUMMARY}

Longitudinal pineapple fruit crown sections were irradiated and studied for their rooting ability.

Groups of 40 sections each were exposed to gamma-ray doses of 500 , $750,1,000,1,500,2,000,2,500,3,000,4,000,8,000,16,000$ and 32,000 rads in two separate experiments. The treated plant material was propagated, with checks, in sterilized soil in metal flats.

The results indicate that at low doses of 500 to 4,000 rads no radiation effect was detected on the rooting of crown sections, proliferation of shoots and shoot stuntiness. Delayed germinal-bud sprouting was observed above 3,000 rads.

Exposures to 8,000 and 16,000 rads reduced rooting of crown sections, retarded sprouting of germinal buds, reduced proliferation of shoots, and caused stuntiness in the initial stage of shoot growth. Exposure to 32,000 rads resulted in killing pineapple vegetative tissue. 
Pineapple appears to be highly resistant to this source of radiation.

\section{RESUMEN}

Se irradiaron secciones longitudinales de la corona de la fruta de la piña y se estudió el efecto radiosensitivo.

En dos experimentos separados, se trataron con rayos gamma grupos de 40 secciones cada uno, a dosis de $500,750,1,000,1,500,2,000,2,500,3,000$, $4,000,8,000,16,000$ y 32,000 rads. Posteriormente, el material irradiado se propagó en un suelo esterilizado conjuntamente con el testigo.

Los resultados indican que las dosis de 500 a 4,000 rads no afectaron el enraizamiento de las secciones de la corona ni la proliferación y vigor de los hijuelos que de éstas se originaron, aunque las dosis en exceso de 3,000 rads retardaron el brote de las yemas germinales.

Las dosis altas de 8,000 y 16,000 rads redujeron el enraizamiento de las secciones de la corona, retardaron el brote de las yemas germinales, redujeron la proliferación de los renuevos y causaron que los hijuelos se achaparrarán. El tratamiento de 32,000 rads causó la muerte de todo el tejido vegetativo de la piña.

La piña puede considerarse como una planta altamente resistente a la irradiación.

\section{LITERATURE CITED}

1. Bauer, $R$., The induction of vegetative mutations in Ribes nigrum. Heriditas 48: 323-37, 1957.

2. Collins, J. L., The Pineapple, Interscience Publishers Inc. New York, N.Y., p. 294, 1960.

3. Einset, J., and Pratt, Ch., Problems and methods of handling irradiated, woody, vegetatively propagated plants, Work Conference on Radiation Induced Mutations, Brookhaven Nat'l. Lab., Mimeo. pp. 114-31, May 23-4, 1956.

4. Hough, L. F., and Weaver, G. M., Irradiation as an aid in fruit variety improvement. I. Mutations in the peach. J. Hered. 50: 59-62, 1959.

5. Lewis, D., and Crowe, L. K., The induction of self-fertility in tree fruits, J. Hort. Sci. 88: 220-25, 1954.

6. Marr, G. S., Select the planting material very carefully for better pineapples, Farming in S. A., Govt. Printer, Pretoria, South Africa pp. 21-9, June, 1965.

7. Nybom, N., The use of induced mutations for the improvement of vegetative propagated plants, Mutation and Plant Breeding, NAS-NRC Pub. 891, pp. 252-94, 1861.

8. Sparrow, A. H., Types of ionizing radiation and their cytological effects, Mutation and Plant Breeding, NAS-NRC Pub. 891, pp. 55-119, 1961.

9. - The role of the cell nucleus in determining radiosensitivity, Brookhaven Lecture Series No. 17, Brookhaven Nat'l Lab., May 6, 1962. 